\title{
The role of exosomal non-coding RNAs in cancer metastasis
}

\author{
Jin-Peng Wang1,2,3, Yan-Yan Tang ${ }^{1,2}$, Chun-Mei Fan' ${ }^{2}$, Can Guo' ${ }^{2}$ Yan-Hong Zhou ${ }^{2}$, \\ Zheng $\mathrm{Li}^{2}$, Xiao-Ling $\mathrm{Li}^{2}$, Yong $\mathrm{Li}^{2,4}$, Gui-Yuan $\mathrm{Li}^{1,2,3}$, Wei Xiong ${ }^{1,2,3}$, Zhao-Yang \\ Zeng ${ }^{1,2,3}$ and Fang Xiong ${ }^{1}$ \\ ${ }^{1}$ The Key Laboratory of Carcinogenesis of the Chinese Ministry of Health, Xiangya Hospital, Central South University, \\ Changsha, Hunan, China \\ ${ }^{2}$ The Key Laboratory of Carcinogenesis and Cancer Invasion of the Chinese Ministry of Education, Cancer Research Institute, \\ Central South University, Changsha, Hunan, China \\ ${ }^{3}$ Hunan Key Laboratory of Nonresolving Inflammation and Cancer, Disease Genome Research Center, The Third Xiangya \\ Hospital, Central South University, Changsha, Hunan, China \\ ${ }^{4}$ Department of Cancer Biology, Lerner Research Institute, Cleveland Clinic, Cleveland, $\mathrm{OH}, \mathrm{USA}$ \\ Correspondence to: Fang Xiong, email: xiongf@csu.edu.cn \\ Zhao-Yang Zeng, email: zengzhaoyang@csu.edu.cn
}

Keywords: exosome; non-coding RNA; tumor microenvironment; tumor metastasis

Received: July 10, 2017 Accepted: October 28, $2017 \quad$ Published: December 21, 2017

Copyright: Wang et al. This is an open-access article distributed under the terms of the Creative Commons Attribution License 3.0 (CC BY 3.0), which permits unrestricted use, distribution, and reproduction in any medium, provided the original author and source are credited.

\section{ABSTRACT}

An increasing number of studies has confirmed that many cells can secrete vesicles or exosomes in eukaryotes, which contain important nucleic acids, proteins and lipids and play important roles in cell communication and tumor metastasis. This paper summarizes the comprehensive function of exosomal non-coding RNAs. Although some studies have shown that exosomes mediate tumor signal transduction, the functional mechanism of the tumor metastasis remains to be elucidated. In this paper, we reviewed the role of exosomal non-coding RNAs in mediating cancer metastasis in the tumor microenvironment to provide new ideas for the study of tumor pathophysiology.

\section{INTRODUCTION}

Tumor metastasis is the main cause of cancer death [1-6]. Metastasis is a multiple-level process that includes tumor cell transit through the basement membrane into the vasculature, survival in the circulation system, gradual outward invasion, and finally colonization to distant organs, dissemination of cancer cells and adaptation to the microenvironment to promote cancer development [7-12]. In the process of tumor metastasis in the tumor microenvironment, studies have confirmed that cancer cells communicate with each other and that the surrounding stromal cells could lead to the occurrence and development of tumor metastasis [13-20]. Exosomes play important roles in the tumor microenvironment and the mechanism of malignant tumor metastasis.

Exosomes consist of a phospholipid bilayer, which is composed mainly of proteins, lipids, carbohydrates and nucleic acids [21-23]. Studies on exosomal noncoding RNAs (ncRNAs) have raised in recent years, such as microRNAs (miRNAs), long non-coding RNAs
(lncRNAs), and circular RNAs (circRNAs). Exosomes can carry these functional biomolecules to receptor cells to promote non adjacent intercellular communication $[24,25]$. The main sources of exosomes in lysosome particles include invagination and the formation of multivesicular bodies, multi-vesicular bodies and serosa release exosomes: receptor cells can ingest exosomes via direct fusion, endocytosis or fusion with exosome surface markers [26]. Exosomes can transmit information to the extracellular matrix to regulate the receptor cells [27-29]. The function of exosomes depends on the cell type [29], which may be involved in the immune response, antigen presentation, cell migration, cell differentiation, tumor invasion and other aspects [30]. The above concepts are illustrated in Figure 1.

Exosomes promote the growth of tumor cells in recipient cells by promoting angiogenesis, invasion, proliferation and diffusion [31, 32]. Exosomes target to stromal cells, immune cells and vascular cells in the tumor microenvironment to promote the occurrence and development of cancer [33]. Studies have shown that 
exosomes can directly regulate the invasion and migration of tumor cells and can promote the directional movement of cells via the activity of biological components of the extracellular matrix (ECM) [34, 35]. Tumor exosomes can promote the growth and spread of tumor cells by affecting the permeability of blood vessels or anchoring distant metastasis sites to change the physiological functions of adjacent or distant cells [36-40]. In this review, we focus on the study of the role of exosomal non-coding RNAs in the development of cancer, which are important molecules in cancer metastasis.

\section{THE ROLE OF EXOSOMAL NON-CODING RNAS IN TUMOR METASTASIS}

\section{Exosomal miRNAs in tumor metastasis}

MicroRNAs (miRNAs) are approximately 22-nucleotide-long small molecules of RNA. miRNAs bind to the target mRNA 3 'UTR to prevent the translation of the target mRNA or promote the degradation of target mRNA at the post transcriptional level, to negatively regulate the target genes, and thus to inhibit or promote tumor metastasis [41-43]. Recently, exosomal miRNAs have been found to play key roles in physiological and pathological processes in eukaryotes [44-47]. The tumor-derived miRNAs and stromal cells of the microenvironment are interrelated with each other, which regulate the tumor progression, angiogenesis, invasion and metastasis and can escape from immune surveillance [48]. The role of exosomal miRNAs in tumor metastasis is summarized in Table 1.

Epithelial-mesenchymal transition (EMT) refers to the loss of the characteristics of epithelial cells and gaining the process of interstitial cell phenotype. This process includes changes in the cell's morphology and phenotype, with invasion and distant metastasis of tumor cells as the initial step [49-51]. Scholars confirmed that stromal cell-derived exosomes transport miRNAs to tumor cells, leading to EMT changes in the morphology and biochemistry of tumor cells. Intercellular communication also affects the occurrence and development of the EMT process. Research has shown that exosomes contain special proteins and miRNAs that could induce phenotypic changes [52]. Recently, researchers have confirmed that exosomes contain $m i R-23 a$, which can influence the occurrence and development of EMT by regulating TGF- $\beta$. Exosomes induce the activation of TCF/LEF and the Wnt pathway in lung cancer cells, which affect the occurrence and development of tumors [53-55]. Exosomal miRNAs can be transferred to the target cells, where they directly modify their target mRNAs [56-60].

The development of tumor metastasis requires the tumor cells to adapt to the new metastasis site. However, for when and how the tumor cells can develop metastasis, the underlying mechanisms remain unclear. Recently, researchers have shown that when a primary tumor reaches to the brain, tumor cells that normally express PTEN lose its expression. When PTEN-deficient metastatic brain cancer cells leave the brain, the expression of PTEN will return to normal levels, and the reversal of PTEN deletion occurs via astrocyte-derived exosomal miR-19a in the brain and spinal cord. The miR-19a targets PTEN to complete the biological behavior [8]. The loss of PTEN in brain tumor cells could increase the secretion of cytokine CCL2, which can restore microglia to metastatic tumors to promote the growth of tumor cells and can protect cancer cells from death. This study provides a new hope for the treatment of cancer metastasis [61-64].

Glycolysis and carbohydrate uptake are aberrantly active during carcinogenesis. Recent studies have shown that exosomal miR-122 can be found in breast cancer cells, which can inhibit the proliferation of primary tumor and increase the effectiveness of nutrients of the precancerous metastasis niche, thereby inducing cancer metastasis. miR-122 inhibits carbohydrate uptake by niche cells by inhibiting glycolytic enzymes and pyruvate kinase. The inhibition of $m i R-122$ can reduce the incidence of brain and lung metastases in vivo [65]. By changing the efficiency of glucose utilization by the susceptible anterior metastatic niche cells, exosomal $m i R-122$ can be adapted to the system's energy metabolism program to promote cancer progression.

DNA methylation, histone modification and miRNAs play important roles in the process of tumor progression by regulating the microenvironment and immune surveillance. Exosomal miRNAs can not only be used as potential markers of malignant tumors, but they are also involved in the internal communication between cancer cells and the microenvironment. The expression of $m i R-24-3 P$ was significantly higher in the plasma of nasopharyngeal carcinoma patients. The miR-24-3P inhibited the proliferation of $\mathrm{T}$ cells and the differentiation of Th1 and Th17 and induced the regulation of T cells. $M i R-24-3 P$ regulated the proliferation and differentiation of T cells, decreased the expression of P-ERK, P-STAT1 and P-STAT3, and increased the expression of P-ATAT5 in cells [66]. FGF11 is a direct target of $m i R-24-3 P$ in the regulation of proliferation and differentiation of $\mathrm{T}$ cells. Many studies have demonstrated that exosomal miRNA is involved in regulating the tumor microenvironment [67-71].

Exosomes can be involved in tumor resistance through intercellular communication by carrying biological information and drug factors. Studies have shown that the occurrence and development of breast cancer are closely related to $m i R-134$ and that the expression level of $m i R-134$ can reduce STAT5B, Hsp90, and $\mathrm{Bcl}-2$ to reduce cell proliferation and promote apoptosis by cisplatin [71]. This study suggests that miR134 can be used as a diagnostic biomarker of breast cancer and may be a potential therapeutic target. Other studies 
have shown that exosomal miR-939 is associated with poor breast cancer prognosis, inhibits VE-cadherin and destroys the barrier function of endothelial cells [72].

Gemcitabine (GEM) is a key drug used in pancreatic ductal adenocarcinoma (PDAC), but PDAC cells can produce chemical resistance after long-term administration. Because resistance is rapidly expanding into PDAC tissue, it is important to look for the mechanisms that produce resistance to chemotherapy. Researchers found that the long-term use of GEM increased the expression of miR-155 in PDAC cells [73]. The increase in $m i R-155$ induced the secretion of exosomes via chemotherapy resistance, which promoted anti-apoptotic activity. Exosomes deliver miR-155 to other PDAC cells. Targeting miR-155 may thus effectively reduce drug resistance. This study found a new therapeutic target for GEM in PDAC as well as a new approach to address metastasis.

Studies have revealed breast cancer-derived exosomal $m i R-200$, which can be taken by recipient cells to acquire metastatic ability [70]. Exosomal miR-1246 can induce cell invasion and migration by regulating the DENN/MADD Domain containing 2D (DENND2D) in breast cancer cells [68]. Exosomal miR-105 could destroy vascular endothelial cells to promote the occurrence and metastasis of ovarian cancer by targeting the tight junction protein ZO-1 [67]. Exosomal miR-200 can directly target E-cadherin's mRNA transcriptional repressors ZEB1 and ZEB2 to increase the expression of E-cadherin and inhibit the movement ability of tumors [74, 75]. Other studies have shown that exosomal $m i R-23 a$ increased significantly in hypoxic lung cancer cells. $m i R-23 a$ can promote angiogenesis by directly targeting prolyl hydroxylase $1 / 2$ (PHD1/PHD2), leading to the accumulation of hypoxiainducible factor- $1 \alpha$ (HIF-1 $\alpha)$ in endothelial cells. At the same time, exosomal $m i R-23 a$ inhibits the tight junction protein (ZO-1), thereby increasing the vascular permeability and migration ability. Hypoxic lung cancer cell-derived exosomal $m i R-23 a$ can promote cancer progression by modulating the tumor vasculature [76].

Glioblastoma is a highly invasive malignant brain tumor that is highly vascularized and associated with high mortality. Kininogen-1 (KNG1) is associated with tumor suppression and antiangiogenic activity in glioblastoma. CTU1, KIAA1274 and RAX regulate KNG1 via miR-138. Following the knockdown of the expression of CTU1, KIAA1274 and RAX in U87 cells and immortalized human endothelial cells (iHEC), KNG1 expression is down-

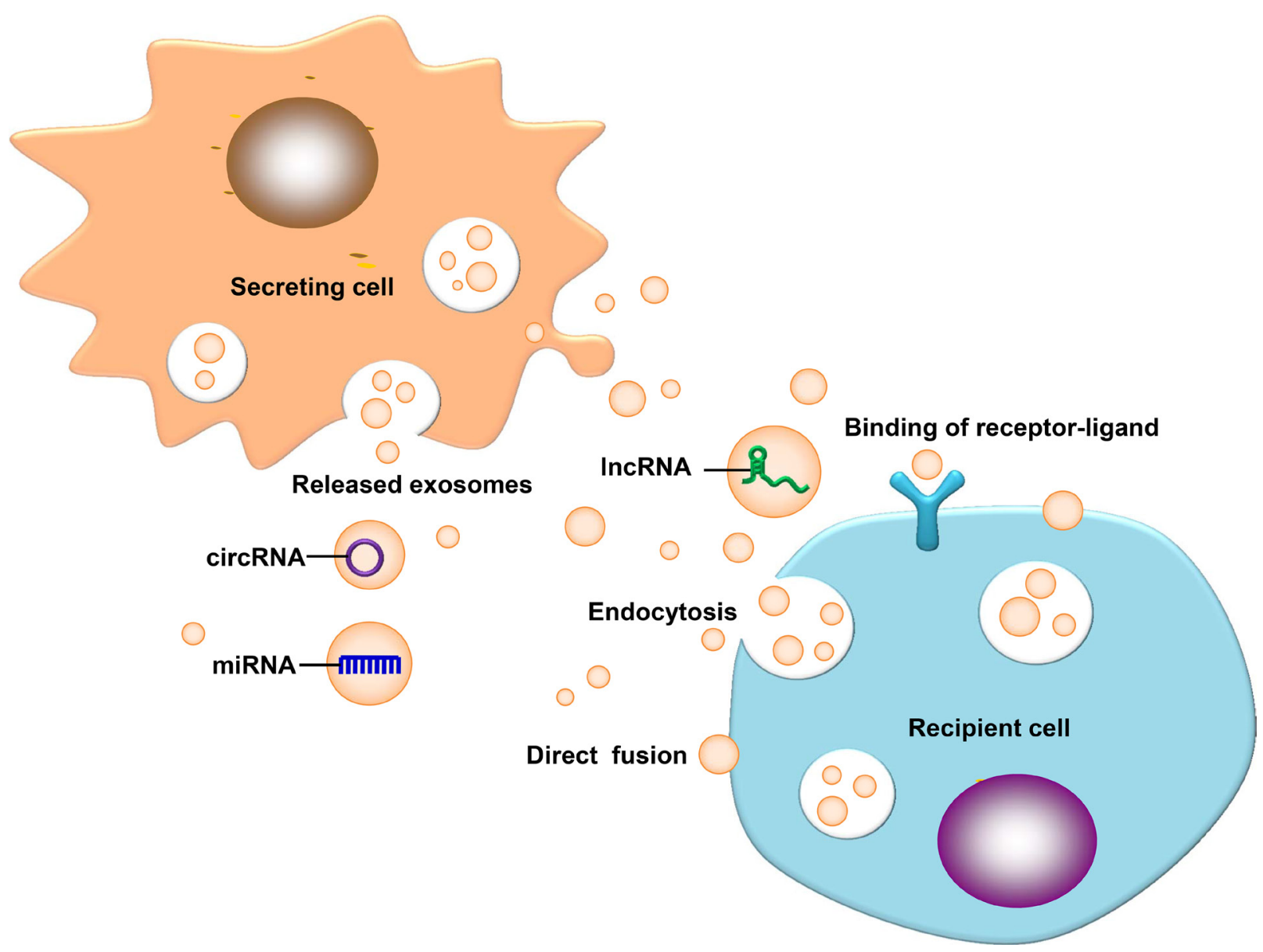

Figure 1: Exosomal ncRNAs ingested by a receptor cell. Exosomal ncRNAs ingested by a receptor cell via direct fusion, endocytosis and binding of receptor ligands. 
Table 1: The biological functions of exosomal miRNAs in tumor metastasis

\begin{tabular}{|c|c|c|c|}
\hline Exosomal miRNA & Role in tumor metastasis & Tumor type & Reference \\
\hline$m i R-23 a$ & $\begin{array}{l}\text { Induce EMT by targeting TGF- } \beta \\
\text { Directly target PHD1/PHD2 and ZO1 to promote lung } \\
\text { cancer cell permeability, angiogenesis and migration } \\
\text { across endothelial cells }\end{array}$ & $\begin{array}{l}\text { Lung canner } \\
\text { Lung cancer }\end{array}$ & $\begin{array}{l}{[54]} \\
{[76]}\end{array}$ \\
\hline$m i R-19 a$ & Promote brain metastasis by inducing PTEN loss & Breast cancer & [8] \\
\hline$m i R-122$ & $\begin{array}{l}\text { Regulate niche cells, glycolytic enzymes, pyruvate kinase, } \\
\text { inhibit glycolysis, and promote tumor metastasis }\end{array}$ & Breast cancer & [65] \\
\hline$m i R-24-3 p$ & Targeting FGF11 to inhibit the function of $\mathrm{T}$ cells & Nasopharyngeal carcinoma & [66] \\
\hline$m i R-134$ & $\begin{array}{l}\text { Inhibit STAT5B, Hsp90 and Bc12, thereby inhibiting } \\
\text { tumor proliferation, invasion and metastasis while } \\
\text { promoting cisplatin-induced apoptosis }\end{array}$ & Breast cancer & [71] \\
\hline$m i R-939$ & $\begin{array}{l}\text { Inhibit VE-cadherin and destroy endothelial barrier } \\
\text { function }\end{array}$ & Breast cancer & [72] \\
\hline$m i R-1246$ & $\begin{array}{l}\text { Regulate cell movement and invasion by regulating } \\
\text { DENND2D of oral squamous cell carcinoma }\end{array}$ & Oral squamous cell carcinoma & [68] \\
\hline$m i R-105$ & $\begin{array}{l}\text { Targeting ZO-1 damages vascular endothelial cells and } \\
\text { promotes metastasis }\end{array}$ & Breast cancer & [67] \\
\hline \multirow[t]{2}{*}{$m i R-200$} & $\begin{array}{l}\text { Directly target the mRNA transcriptional repressor } \\
\text { ZEB1, E-cadherin, ZEB2, up-regulate the expression of } \\
\text { E-cadherin, and inhibit motility in cancer }\end{array}$ & Ovarian cancer & [74] \\
\hline & $\begin{array}{l}\text { It is absorbed by recipient cells so they can develop } \\
\text { metastasis }\end{array}$ & Breast cancer & [70] \\
\hline$m i R-193 a$ & $\begin{array}{l}\text { Interaction with the MVP, which can block the release of } \\
\text { miR-193a after exocytosis, can cause the accumulation of } \\
\text { miR-193a in donor cells and inhibit tumor development }\end{array}$ & Colon cancer & [28] \\
\hline$m i R-142-3 P$ & $\begin{array}{l}\text { It is selectively sorted out to promote malignant } \\
\text { phenotypes both inside and outside the cell }\end{array}$ & Oral carcinoma & [79] \\
\hline$m i R-320 a$ & $\begin{array}{l}\text { MiR-320a-PBX3 inhibits the activation MAPK pathway } \\
\text { and the occurrence of EMT, and it down-regulates the } \\
\text { expression of CDK2 and MMP2, thereby inhibiting tumor } \\
\text { development }\end{array}$ & Liver cancer & [80] \\
\hline \multirow[t]{2}{*}{$m i R-21$} & $\begin{array}{l}\text { Exosomes transport the stromal cell derived miR- } 21 \text { to } \\
\text { ovarian cancer cell. MiR- } 21 \text { targeting APAF1 induces } \\
\text { resistance to paclitaxel in ovarian cancer cells }\end{array}$ & Ovarian cancer & [63] \\
\hline & $\begin{array}{l}\text { Down-regulation of PTEN to activate the PIK } 3 / \text { AKT } \\
\text { signaling pathway and promote the cisplatin resistance of } \\
\text { gastric cancer cells }\end{array}$ & Gastric cancer & [120] \\
\hline$m i R-155$ & $\begin{array}{l}\text { Exosomes transport miR- } 155 \text { to other PDAC cells, } \\
\text { effectively attenuating drug resistance }\end{array}$ & Pancreatic ductal adenocarcinoma & [73] \\
\hline$m i R-214$ & $\begin{array}{l}\text { Down-regulation of the expression of PTEN protein } \\
\text { results in the secretion of large amounts of IL-10 by } \\
\text { Tregs, which results in the immune escape of the host and } \\
\text { tumor growth }\end{array}$ & Lung cancer & [117] \\
\hline$m i R-221$ & $\begin{array}{l}\text { Exosomes transfer miR-221 to tumor cells and can bind } \\
\text { to hormone therapy targets, resulting in tumor HTR }\end{array}$ & Breast cancer & {$[122]$} \\
\hline$m i R-138$ & $\begin{array}{l}\text { The expression of miR-138 can increase angiogenesis. } \\
\text { CTU1, KIAA1274 and RAX regulate KNG1 by miR-138 }\end{array}$ & Glioma & [77] \\
\hline
\end{tabular}

regulated, which results in the up-regulation of oncogenic EGFR signaling and induces angiogenesis in a mouse xenograft model. Knockdown of the expression of KNG1, CTU1, KIAA1274 or RAX can increase the expression of U87 cell-derived exosomal miR-138 and enhance the angiogenesis of iHEC to promote cancer development [77].

Exosomes are new mediators of intercellular communication. In addition to the fact that the exosomes can affect the regulation of recipient cells, whether the release of exosomes affects donor cells remains uncertain. Recently, scholars have innovatively proposed that major vault protein (MVP)-mediated tumor suppressor miRNAs can be selectively separated to the body to promote the development of the tumor process $[28,78]$. Many studies have confirmed that miR-193a can interact with the MVP and that the MVP promotes the release of $m i R-193 a$ from 
the donor cells via the circulation of blood, consequently promoting tumor development. The amount of exosomal miR-193a released would decrease after knocking down the MVP, which would result in the accumulation of $m i R$ $193 a$ in cells and decrease the development of tumor. miR-193a raises from the Ccnd 2 and cMyc by targeting Caprin1, which retards the cell cycle G1 phase and inhibits cell proliferation. At the same time, they proposed that advanced patients had higher levels of exosomal miR$193 a$.

Through further investigation, we found that oral cancer cells can release miR-142-3P by selecting the extracellular vesicles, thus promoting the malignant phenotype both inside and outside the cells [79]. Inhibiting the exosomal protein Rab27A output, which can stop the release of exosomes, is thought to increase the expression levels of $m i R-142-3 p$, $m i R-150-5 p$, and $m i R-223-3 p$. Increasing $m i R-142-3 p$-targeted TGFBR1, which can downgrade the expression of TGFBR1 in donor cells, can reduce the formation of the malignant phenotype. The reverse validation by increasing the release of $m i R-142-$ $3 p$ in the donor cells, which can be ingested by receptors on endothelial cells, reduced the activity of TGFBR1, eventually enabling the development of tumor.

The loss of cancer-associated fibroblast-derived exosomal miR-320a can promote the proliferation and metastasis of hepatocellular carcinoma cells. MiR-320a can be combined with the downstream target genes PBX3 as a tumor suppressor miRNA to inhibit the liver cancer cell proliferation, migration and metastasis. miR-320a$P B X 3$ inhibits the active pathway of the MAPK and EMT and reduces the expression of dependent cytokinase 2 (CDK2) and MMP2 to inhibit tumor development [80].

\section{Exosomal lncRNAs in tumor metastases}

LncRNA are nucleotides longer than 200 nucleotides in length that do not encode proteins. The approaches to regulate genes of lncRNAs are varied. One of the most important ways is to directly target the transcription of target genes through base complementation and binding to target genes or by indirectly regulating target genes upstream or downstream of gene transcription [62, 81-88]. Although this process plays an important role in tumor development, the mechanisms underlying the relationship between lncRNAs and tumor metastasis need further study to identify more treatment approaches [17, 89-93]. The role of exosomal lncRNAs in tumor metastases is summarized in Table 2.

Recent studies have confirmed that lncRNA $H O X$ transcript antisense RNA (HOTAIR) is associated with poor prognosis for many types of cancers. There are a variety of lncRNAs in the urine of bladder cancer patients, including HOTAIR, HOX-AS-2, the MALAT1, SOX2, OCT4 HYMA1, LINC00477, LOC100506688, and OTX2AS1. Knockdown of HOTAIR in bladder cancer cell lines will reduce invasion and migration. More significantly, the loss of the HOTAIR will affect the changes of related EMT genes, e.g., SNAI1, TWIST1, ZEB1, ZO1, MMP1, LAMB3, and $L A M C 2$ [62]. The exosomal lncRNAs originating from urine can be used as new molecular markers and targets for molecular therapy, thus providing cancer treatments with more effective solutions.

CD90+ cancer cells are cancer stem cells that can promote cancer invasion and metastasis. The exosomes released by CD90+ cells (not parent liver cancer cells) are rich in IncRNAH19, which can regulate endothelial cells and promote angiogenesis and adhesion between cells. This study showed a new kind of regulating mechanism. The cancer stem cell sample CD90+ cells can promote angiogenesis and the tumor microenvironment [94]. This research proposed that lncRNAH19 can also serve as a potential therapeutic target in liver cancer. Other studies showed that exosomal lncRNA TUC339, which derives from liver cancer cells, can regulate the tumor microenvironment and can be used to adjust the growth and adhesion ability of tumor cells via the horizontal transformation of exosomes in cells [95].

In recent years, researchers have found that an lncRNA called lncARSR (lncRNA Activated in RCC with Sunitinib Resistance) is closely related to sunitinib resistance in clinical treatment [60]. IncARSR can be used as a competitive endogenous RNA (ceRNA), when combined with $m i R-34 / m i R-449$, to promote the expression of AXL, c-MET in renal carcinoma cells, and then realize the promotion of sunitinib resistance. However, this bioactive lncARSR is delivered to the recipient cells by exosomes, thereby contributing to the spread of sunitinib drug resistance. Targeted blockade of lncARSR or the use of AXL/c-MET inhibitors may aid in treating renal cell carcinoma that is resistant to sunitinib. lncARSR may serve as an effective molecular marker and intervention target to improve the therapeutic efficacy of sunitinib in renal cell carcinoma and provide a new approach and perspective for the individualized target therapy of renal cell carcinoma.

Many studies have shown that the expression of long noncoding RNA ZFAS1 has increased in cancers, and some scholars have linked ZFAS1 to the exosomes. The expression of long noncoding RNA ZFAS1 is upregulated in the serum of patients with gastric cancer, in whom exosomes can promote the proliferation and migration of gastric cancer cells by transmitting the ZFAS1 [96]. Exosomes can up-regulate cyclin D1 and accelerate the cell cycle. Bcl-2 simultaneously increases time the down-regulation of Bax, which can increase the level of ERK phosphorylation. Exosomal ZFAS1 can increase the proliferation and invasion of gastric cancer cells. Many studies confirmed that the expression of ZFAS1 is upregulated in cancers and proved that it can compete with $m i R-150$ as ceRNA; further, the expression of $m i R-150$ can inhibit ZFAS1 [97]. Other studies have shown that 
ZFAS1 is associated with EMT in gastric carcinoma [98]. Whether these biological mechanisms are associated with biological function of exosomes requires further research. The study confirmed that ZFAS1 may play a role in the tumorigenesis of gastric cancer and can serve as a novel target for treating gastric cancer.

Research found that the IncRNAs in plasma can be protected by exosomes and expressed stably, and researchers have confirmed that the expression of LINC00152 is significantly increased in the plasma of gastric cancer patients. Its expression level is almost equal in plasma and exosomes [99]. LINC00152 can be used as a potential and stable molecular marker of gastric cancer. Some studies confirmed that exosomal lncRNAs play important roles in tumor development and progression. HOTAIR, MALAT1 and MEG3 can be used as targets of cervical cancer in early diagnosis [100]. The lncRNA H19 can increase the expression of angiogenic factor VEGF and its receptor VEFG-R1, both of which can be used as potential drug targets in hepatocellular carcinoma [101]. In the development of cancer, many studies have confirmed that a variety of lncRNAs is closely related to the development of cancer. The lncRNAs HULC, lncRNAH19, HEIH, and $M V I H$ can promote the growth of cancer cells. The lncRNAs HOTAIR and PVT1 can promote the proliferation of cancer cells. The lncRNAs $M A L A T 1, L E T$ and $A T B$ can promote the metastasis of cancer cells. Whether these exosomal lncRNAs are closely related to cancers deserves further discussion $[62,100$, 101].

\section{Exosomal circRNAs in tumor metastasis}

circRNA is formed by a downstream 5 splice site that is associated with an upstream 3 splice site and is more stable than linear RNA. Its formation can be divided into the phases of intron cyclization, Lasso driving cyclization, intron pairing, driving and cyclization. In the beginning, circRNAs were considered a by-product of splicing errors and did not receive extensive attention. In recent years, with the development of sequencing technology, more circRNAs have been identified [102-105].

Exosomal circRNA is novel and stable. It may serve as a new tumor marker and provide new ideas for the diagnosis and prognosis of tumors. circRNAs may play an important role in cell communication. Some recent studies have confirmed that circRNAs can be used as molecular sponges for miRNAs [106-108], which can competitively inhibit the biological activity of miRNA. CiRS-7 can be used as a natural molecular sponge for miRNA-7 to regulate gene expression, regulate transcription and splicing, and regulate parental gene transcription [81, 109]. Researchers speculated that functional exosomal circRNAs participate in intercellular communication. $c i R S-7 / C D R 1$ can serve as a miRNA molecular sponge, which can combine with special miRNA, and can transfer biological information to a specific position to achieve the efficient transmission of biological information and thereby promote the spread of cancer [102].

Studies have shown that the development of colon cancer is closely related to circRNA. The content of exosomal circRNAs is far greater than that found in cells [110]. CircRNAs may regulate the development of colon cancer and serve as molecular markers for cancer.

The expression levels of exosomal circRNAs are stable and abundant. However, the mechanism is unknown and may be attributed to the special protection of exosomes, the features of a specific sequence, or the protection of certain proteins [103]. Exosomal circRNAs are likely to become new markers for cancer therapy and molecular therapeutic targets.

\section{THE MECHANISM OF EXOSOMAL NON- CODING RNAS INVOLVED IN TUMOR METASTASIS}

Invasion and metastasis are the basic characteristics of malignant tumors. They are also the pathological bases for tumor recurrence, disease deterioration and, ultimately, death. There are many mechanisms that affect tumor metastasis and are related to a variety of pathways. Exosomal noncoding RNA can also contribute to tumor metastasis through a variety of mechanisms [111]. Figure 2 shows that the pathways of exosomal ncRNAs regulate tumor metastasis.

\section{Transmission of oncogenes}

Exosomal non-coding RNA can affect the proliferation, invasion and migration of tumor cells through specific biological action and can further affect the occurrence and development of tumor metastasis [39]. $m i R-1246$, for instance, regulates the invasion and metastasis by regulating DENND2D. miR-105 destroys vascular endothelial cells by targeting the tight junction protein ZO-1 and promotes metastasis. The lncRNA ZFAS1 promotes the proliferation and migration of gastric cancer cells via the transmission of the exocrine. miR-134 can inhibit STAT5B, Hsp90 and Bcl2 and can further inhibit the proliferation, invasion and metastasis of tumor cells. $m i R-142-3 P$ can be selectively isolated from exosomes, thus promoting the development of the malignant phenotype of tumor cells.

\section{Interfere with the immune system to promote tumor metastasis}

Tumor cells can evade the immune response through various mechanisms, such as a lack of histocompatibility complex (MHC)I and the expression of MHC II, mutation and degradation of tumor associated antigen, and blocking immune molecules to increase the tolerance of the immune system. Tumor cells can also inhibit NK cells and raise CTL cells by regulating the output of VEGF, 
Table 2: The biological functions of exosomal IncRNAs in tumor metastasis

\begin{tabular}{|c|c|c|c|}
\hline Exosomal IncRNA & Role in tumor metastasis & Tumor type & Reference \\
\hline $\begin{array}{l}\text { HOTAIR, } \\
\text { MALAT1, } \\
\text { MEG3 }\end{array}$ & As a target for the early diagnosis of cervical cancer & Cervical cancer & {$[100]$} \\
\hline $\operatorname{lncARSR}$ & $\begin{array}{l}\text { The competitive combination of } \mathrm{miR}-34 / \mathrm{miR}-449 \\
\text { increase the expression levels of AXL and c-MET } \\
\text { and promote the dissemination of sunitinib resistance } \\
\text { through exosomes }\end{array}$ & Renal carcinoma & [60] \\
\hline$H 19$ & $\begin{array}{l}\text { Increasing the expression of VEGF and its receptor } \\
\text { VEGF-R1, which may serve as a potential target for } \\
\text { HCC }\end{array}$ & Liver cancer & [101] \\
\hline ZFAS1 & $\begin{array}{l}\text { Promote the proliferation and migration of gastric } \\
\text { cancer cells through the transmission of the exosome }\end{array}$ & Gastric cancer & [96] \\
\hline LINC00152 & $\begin{array}{l}\text { The expression in exosome increased significantly in } \\
\text { patients }\end{array}$ & Gastric cancer & [99] \\
\hline TUC339 & $\begin{array}{l}\text { Regulating the microenvironment of hepatoma cells } \\
\text { by intracellular transfer of the exosome, thereby } \\
\text { regulating the growth and adhesion of tumor cells }\end{array}$ & Liver cancer & [95] \\
\hline
\end{tabular}

IL-10, TGF- $\beta$, and adenosine ROS immunosuppressive molecules, thus damaging the immune response [112], and are not recognized by immune cells to escape immune surveillance $[113,114]$. The improvement of tumor cell proliferation and the increased instability can cause the development of different types of antigens. Exosomal CD39 and CD73 exist in cancer cells. These two molecules can generate adenosines, which can restrain immunity; then, tumor cells can regulate immune cells [115]. Exosomes can influence the development of tumor metastasis by affecting the immune function, such as $m i R-24-3 p$ targeting FGF11 to inhibit T cell function. Macrophages can secrete exosomes that contain abundant $m i R-155$, which promotes the expression of TNF-a, IL6 , and IL-23 while increasing the expression of CD40, CD63, CD81, MCH-I, MyD88, and NF-kB. The research has shown that miR-155 is involved in the inflammatory response [116]. Studies have reported that tumor-derived exosomal miR-214 inhibited the PTEN protein expression level to induce the secretion of IL-10 by Tregs, leading to the host organism immune escape to promote tumor growth [117].

\section{Participate in drug resistance to promote tumor metastasis}

Multiple drug resistance in tumor cells and tumor metastasis are the two main factors contributing to the failure of cancer treatment. Multidrug resistance (MDR) in tumor cells can cause resistance to drugs that are administer to inhibit cell growth and can cause toxicity. Numerous studies have shown that exosomes blockade can block the response to cell growth therapy [118]. Studies have reported that breast cancer cells can transmit $m i R-100, m i R-222$, miR-30a, and $m i R-17$ via exosomes to decrease the drug resistance to doxorubicin and paclitaxel [119]. Exosome can participate in the mechanisms underlying cancer drug resistance to promote tumor metastasis. miR-21 moves from the stromal cells to the ovarian cancer cells via the transport of exosomes and targets APAF1 to cause Taxol resistance in ovarian cancer cells [63]. There have also been reports that macrophages can deliver miR-21 to the stomach cancer cells via exosomes, thereby inhibiting the apoptosis of gastric cancer cells by down-regulating PTEN to activate the PIK3/AKT signaling pathway, and can promote cisplatin resistance in gastric cancer cells [120]. The competitive combination of $l n c A R S R$ with $m i R-34 / m i R-449$ increases the expression levels of AXL and c-met though exosomes to promote the spread of drug resistance. An increase in $m i R-155$ in the pancreatic duct adenocarcinoma (PDAC) can induce exosome secretion. By promoting the antiapoptotic activity produced by chemotherapy drug resistance, exosomal miR-155 will be delivered to other PDAC cells and can effectively weaken gemcitabine (GEM) resistance $[76,121]$. The fibroblasts secrete $m i R$ 221 into tumor cells, which can bind to hormone therapy targets, resulting in tumor hormone therapy resistance (HTR) [122].

\section{Involvement in tumor metabolism to promote tumor metastasis}

Tumor cell metabolism refers to normal cells that are under the action of a carcinogenic factor and develop a continuous proliferation of tumor cells. Similar to increases in glucose intake, lactic acid accumulation or nucleic acid synthesis can reinforce metabolic 
changes. The three most remarkable features of tumor cells, including immortality, mobility and the loss of contact inhibition, have the most direct relationship with tumor cell metabolism. Molecular biological studies of metastatic tumors have found that the main carcinogenic signaling pathways converge at the end of the tumor cell metabolism. Metabolic changes are essential in the development of tumor cells. Therefore, some research teams have explored the mechanisms of tumor metastasis from the perspective of tumor sugar metabolism; e.g., miR122 inhibits glycolysis by downregulating the pyruvate kinase. Recent studies have reported that the pyruvate kinase M2 (PKM2) plays an important role in the release of exosomes [65]. This process is a key step in exosome secretion, and the release of tumor cells is closely related to the general and metabolic transformation of tumor cells.

\section{Participate in EMT to promote tumor metastasis}

EMT is an important process in the early stage of tumor invasion and metastasis. An important marker of EMT is the down-regulation of E-cadherin. Many transcription factors can inhibit the expression of E-cadherin. For example, Snail/Slug family proteins, Twist, ZEB1, SIP1 and the E12/E47, Wnt, TGF- $\beta$, and nuclear factor- $\kappa \mathrm{B}(\mathrm{NF}-\kappa \mathrm{B})$ pathways play an important role in the EMT process. They can promote the occurrence of EMT by affecting the transcription inhibitory factor of EMT [51]. Many studies have shown that a variety of exosomal miRNAs may influence the signaling molecules that are related to the EMT pathway. Exosomal miRNAs can promote or inhibit tumor metastasis by influencing the occurrence of EMT. For example, exosomal miR-23a can regulate the development of EMT by influencing TGF- $\beta$. Exosomes can induce the transcriptional activation of TCF/LEF and activate the Wnt pathway in lung cancer cells to affect the occurrence and development of tumor metastasis. miR-939 inhibits VE-cadherin and destroys endothelial barrier function. $m i R-200$ can directly target E-cadherin's transcriptional repressors ZEB1 and ZEB2 and can up-regulate the expression of E-cadherin and inhibit the motility of mRNA. miR-320a-PBX3 can inhibit the activation pathway of MAPK, thereby inhibiting the occurrence of EMT and down-regulating the expression of cyclin dependent kinase 2 (CDK2) and MMP2. Therefore, $m i R-320 a-P B X 3$ can inhibit tumor development. The loss of p $85 \alpha$ expression in the stroma of breast cancer can cause stromal fibroblasts to acquire the characteristics of cancer associated fibroblasts (CAF). Exosomes carry Wnt10b and induce EMT via the classical Wnt pathway,

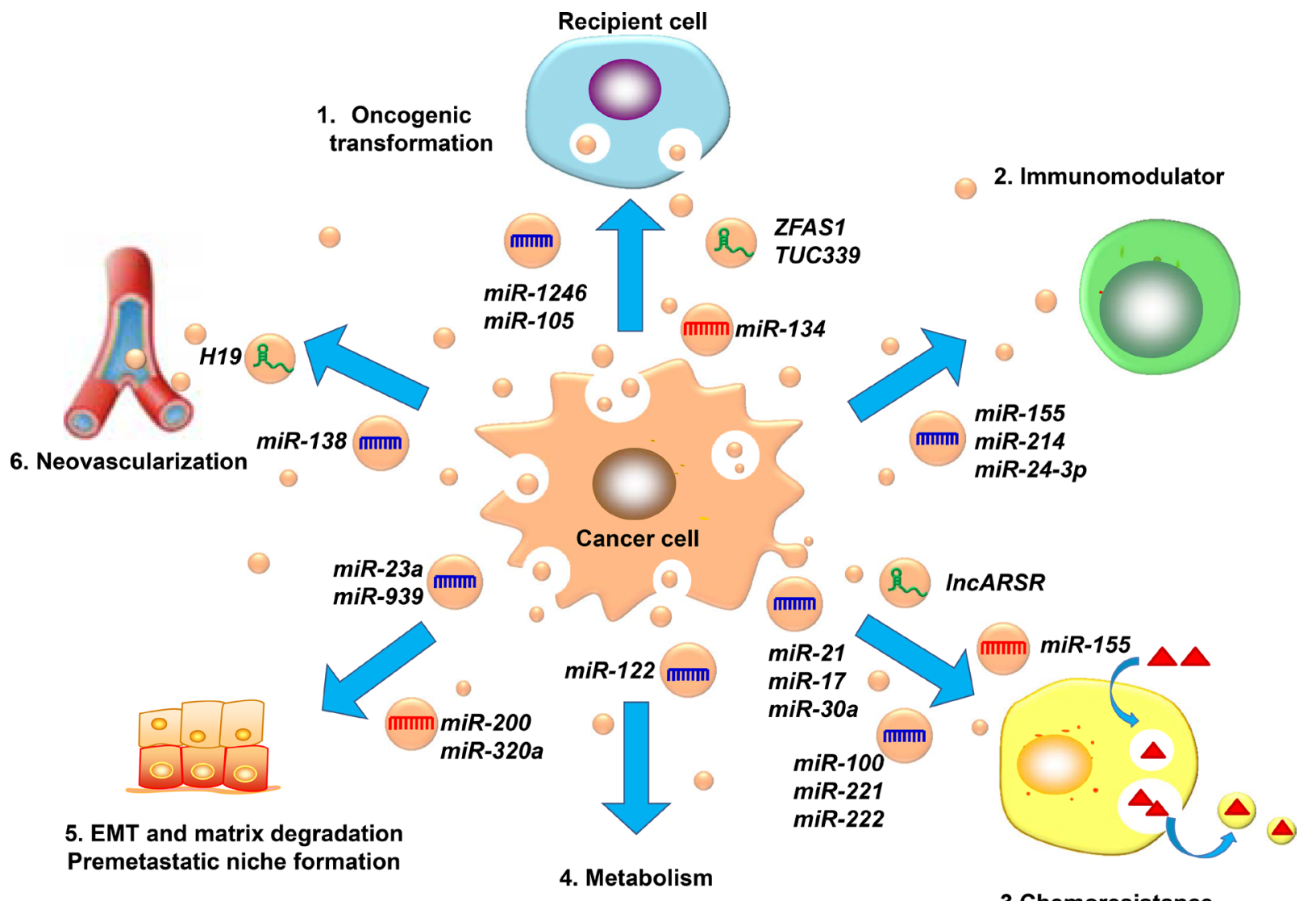

Figure 2: The mechanisms of the exosomal ncRNAs involved in cancer metastasis. (1). Horizontal transmission of oncogenes, (2). Regulate the immune system as immunomodulators, (3). Participate in tumor chemotherapy resistance, (4). Regulate tumor metabolism, (5). Influence the progression of EMT and cancer premetastatic niches, (6). Promote angiogenesis. 
which can promote cancer progression by modifying the stromal cells and epithelial tissue remodeling of the tumor micro-environment [123].

\section{Modulate vascular system to promote tumor metastasis}

miR-138, an exosomal ncRNA that is derived from glioblastoma, enhances tumor angiogenesis and promotes cancer development. The exosomes originating from glioma stem cells promote the angiogenesis of endothelial cells via the $m i R-21 / \mathrm{VEGF}$ signaling pathway [124]. The increased expression of angiogenic factor (VEGF) and its receptor VEGF-R1 caused by lncRNA H19 affects the development of metastatic tumors.

Many researchers have also explored the effects and functions of exosomal ncRNAs through other approaches. For example, some non-coding RNAs in exosomes can play vital biological roles by acting as ceRNA. Further, lncARSR combined with miR-34/miR-449 can increase the expression levels of AXL and c-MET. This promotes the development of metastatic disease by promoting the dispersion of drug resistance. $m i R-19 a$ promotes brain metastasis by inducing the loss of PTEN [8]. We need to conduct more in-depth studies to explore new pathways by which exosomal ncRNAs can promote cancer metastasis.

\section{Summary}

In recent years, studies on the mechanism of exosomal non-coding RNAs have increased. However, deeper mechanisms are still to be found in the exosomes. The main challenges in studying exosomes include how they participate in the physiological and pathological processes and dissecting the transfer of exosomes from cell to cell $[125,126]$. In this review, we have summarized various exosomal non-coding RNAs that play key roles in tumor metastasis. This review provides a detailed description of the function of exosomal ncRNAs, which will offer new insights and provide novel therapeutic approaches in malignant tumor metastasis.

Exosomes are membranous vesicles that are secreted into the extracellular space by a variety of cells and play important biological functions in intercellular communication. Many sources of exosomal ncRNAs have been shown to be closely related to human malignancies. As the potential functions of exosomes are gradually discovered, it is critical to explore the structures of these vesicles and their social domains. This will give aid in studying the deeper functional mechanisms of exosomes $[13,127,128]$. Currently, the main research approach is to explore the relative miRNAs and protein levels of exosomes [129, 130]. We believe that the lncRNA, circRNA, and other new components will be used in a broader field of exosome investigations [131]. This method of transferring small packages will provide new perspectives for cancer treatment and prognosis and will give more novel ideas to examine tumor metastasis and unique clinical paths.

Exosomal ncRNAs may serve as very important biomarkers for disease diagnosis, prognosis, and treatment. Many studies have reported that there are important cancer-associated RNAs and protein markers in exosomes, but because of their small size and low density, it is not easy to isolate exosomes. Because of the complexity of extraction methods, it is difficult to study the exosomes. The current mainstream exosome isolation techniques include ultracentrifugation-based isolation techniques, ultrafiltration, immunoaffinity capture-based techniques, and exosome precipitation $[132,133]$. Recently, a new method for the rapid isolation and identification of exosomes has been found. The core of this technology is an alternating current electrokinetic (ACE) microarray device. Such a device may have more than 1000 electrodes, and its surface is coated with a thin layer of porous water gel. In the dielectrophoretic high field area, the exosome mass is enriched. Exosomes are enriched at the chip electrodes and can be analyzed and identified directly via scanning electron microscopy and immunofluorescence [134]. In addition, the novel microfluidics-based isolation techniques may make it more convenient to explore the exosomal ncRNAs $[135,136]$. There are also many emerging technologies for extracting exosomes. The advent of more advanced exosome extraction techniques will greatly accelerate the development of exosomal ncRNA research.

Exosomal ncRNAs play important roles in malignant tumor metastasis. They are hoped to have an indispensable role in targeted drug delivery and clinical therapy. At the same time, the development of more efficient exosome separation techniques will promote exosome research. The anomalous expression levels of exosomal ncRNA may indicate cancer or cancer progression. Exosomal ncRNAs are thus promising biomarkers. Further study of exosomal ncRNAs may provide an effective minimally invasive strategy for the diagnosis, prognosis and treatment of cancer. The discoveries of exosomal ncRNAs have opened a potential market for more exciting clinical applications in the near future.

\section{Abbreviations}

ncRNA: non-coding RNA; LncRNA: Long noncoding RNA; miRNA: micro RNA; ECM: Extracellular matrix; EMT: Epithelial-mesenchymal transition; PDAC: Pancreatic ductal adenocarcinoma; GEM: Gemcitabine; HIF-1 $\alpha$ : Hypoxia-inducible factor-1 $\alpha$; ZO-1:Tight junction protein; iHEC: immortalized human endothelial cells; MVP: Major vault protein; HOTAIR: HOX transcript antisense RNA; ceRNA: Competitive endogenousRNA; lncARSR: lncRNA Activated in RCC with Sunitinib Resistance; CAF: Cancer associated fibroblasts; MDR: 
Multidrug resistance; HTR: Hormone therapy resistance; PTEN: Phosphatase and tensin homolog.

\section{Author contributions}

$\mathrm{WX}$ and $\mathrm{ZYZ}$ designed and revised the manuscript. JPW wrote the manuscript and drew figures. YYT and CMF collected the related paper and created the tables. FX, CG, YHZ, ZL, XLL, YL and GYL participated in the design of the review. All the authors read and approved the final version of the review.

\section{ACKNOWLEDGMENTS}

Not applicable.

\section{CONFLICTS OF INTEREST}

None.

\section{FUNDING}

This work was supported by the National Natural Science Foundation of China (81672683, 81472531 and $81402009)$, the Natural Science Foundation of Hunan Province (2015JJ1022, 2016JC2035 and 2017SK2105), and the 111 project (111-2-12).

\section{REFERENCES}

1. Zhang W, Fan S, Zou G, Shi L, Zeng Z, Ma J, Zhou Y, Li X, Zhang X, Li X, Tan M, Xiong W, Li G. Lactotransferrin could be a novel independent molecular prognosticator of nasopharyngeal carcinoma. Tumour Biol. 2015; 36:675-83. https://doi.org/10.1007/s13277-014-2650-1.

2. Yan Q, Zeng Z, Gong Z, Zhang W, Li X, He B, Song Y, Li Q, Zeng Y, Liao Q, Chen P, Shi L, Fan S, et al. EBV-miRBART10-3p facilitates epithelial-mesenchymal transition and promotes metastasis of nasopharyngeal carcinoma by targeting BTRC. Oncotarget. 2015; 6:41766-82. https://doi. org/10.18632/oncotarget.6155.

3. Bo H, Gong Z, Zhang W, Li X, Zeng Y, Liao Q, Chen P, Shi L, Lian Y, Jing Y, Tang K, Li Z, Zhou Y, et al. Upregulated long non-coding RNA AFAP1-AS1 expression is associated with progression and poor prognosis of nasopharyngeal carcinoma. Oncotarget. 2015; 6:20404-18. https://doi. org/10.18632/oncotarget.4057.

4. Zeng Z, Huang H, Zhang W, Xiang B, Zhou M, Zhou Y, Ma J, Yi M, Li X, Li X, Xiong W, Li G. Nasopharyngeal carcinoma: advances in genomics and molecular genetics. Sci China Life Sci. 2011; 54:966-75. https://doi. org/10.1007/s11427-011-4223-5.

5. Yang L, Tang Y, He Y, Wang Y, Lian Y, Xiong F, Shi L, Zhang S, Gong Z, Zhou Y, Liao Q, Zhou M, Li X, et al. High Expression of LINC01420 indicates an unfavorable prognosis and modulates cell migration and invasion in nasopharyngeal carcinoma. J Cancer. 2017; 8:97-103. https://doi.org/10.7150/jca.16819.

6. Tang Y, He Y, Shi L, Yang L, Wang J, Lian Y, Fan C, Zhang P, Guo C, Zhang S, Gong Z, Li X, Xiong F, et al. Co-expression of AFAP1-AS1 and PD-1 predicts poor prognosis in nasopharyngeal carcinoma. Oncotarget. 2017; 8:39001-11. https://doi.org/10.18632/oncotarget.16545.

7. Aleckovic M, Kang Y. Welcoming Treat: AstrocyteDerived Exosomes Induce PTEN Suppression to Foster Brain Metastasis. Cancer Cell. 2015; 28:554-6. https://doi. org/10.1016/j.ccell.2015.10.010.

8. Zhang L, Zhang S, Yao J, Lowery FJ, Zhang Q, Huang WC, Li P, Li M, Wang X, Zhang C, Wang H, Ellis K, Cheerathodi $\mathrm{M}$, et al. Microenvironment-induced PTEN loss by exosomal microRNA primes brain metastasis outgrowth. Nature. 2015; 527:100-4. https://doi.org/10.1038/nature15376.

9. Liao Q, Guo X, Li X, Xiong W, Li X, Yang J, Chen P, Zhang W, Yu H, Tang H, Deng M, Liang F, Wu M, et al. Prohibitin is an important biomarker for nasopharyngeal carcinoma progression and prognosis. Eur J Cancer Prev. 2013; 22:6876. https://doi.org/10.1097/CEJ.0b013e328354d351.

10. Yang Y, Liao Q, Wei F, Li X, Zhang W, Fan S, Shi L, Li X, Gong Z, Ma J, Zhou M, Xiang J, Peng S, et al. LPLUNC1 inhibits nasopharyngeal carcinoma cell growth via downregulation of the MAP kinase and cyclin D1/E2F pathways. PLoS One. 2013; 8:e62869. https://doi.org/10.1371/journal. pone.0062869.

11. Song Y, Li X, Zeng Z, Li Q, Gong Z, Liao Q, Li X, Chen P, Xiang B, Zhang W, Xiong F, Zhou Y, Zhou M, et al. Epstein-Barr virus encoded miR-BART11 promotes inflammation-induced carcinogenesis by targeting FOXP1. Oncotarget. 2016; 7:36783-99. https://doi.org/10.18632/ oncotarget.9170.

12. Wang M, Zhao J, Zhang L, Wei F, Lian Y, Wu Y, Gong Z, Zhang S, Zhou J, Cao K, Li X, Xiong W, Li G, et al. Role of tumor microenvironment in tumorigenesis. J Cancer. 2017; 8:761-73. https://doi.org/10.7150/jca.17648.

13. Costa-Silva B, Aiello NM, Ocean AJ, Singh S, Zhang H, Thakur BK, Becker A, Hoshino A, Mark MT, Molina H, Xiang J, Zhang T, Theilen TM, et al. Pancreatic cancer exosomes initiate pre-metastatic niche formation in the liver. Nat Cell Biol. 2015; 17:816-26. https://doi. org/10.1038/ncb3169.

14. Melo SA, Sugimoto H, O'Connell JT, Kato N, Villanueva A, Vidal A, Qiu L, Vitkin E, Perelman LT, Melo CA, Lucci A, Ivan C, Calin GA, et al. Cancer exosomes perform cell-independent microRNA biogenesis and promote tumorigenesis. Cancer Cell. 2014; 26:707-21. https://doi. org/10.1016/j.ccell.2014.09.005.

15. Zhou Y, Liao Q, Li X, Wang H, Wei F, Chen J, Yang J, Zeng Z, Guo X, Chen P, Zhang W, Tang K, Li X, et al. HYOU1, Regulated by LPLUNC1, Is Up-Regulated in Nasopharyngeal Carcinoma and Associated with Poor Prognosis. J Cancer. 2016; 7:367-76. https://doi. org/10.7150/jca.13695. 
16. Zeng Z, Fan S, Zhang X, Li S, Zhou M, Xiong W, Tan M, Zhang W, Li G. Epstein-Barr virus-encoded small RNA 1 (EBER-1) could predict good prognosis in nasopharyngeal carcinoma. Clin Transl Oncol. 2016; 18:206-11. https://doi. org/10.1007/s12094-015-1354-3.

17. Zeng Z, Bo H, Gong Z, Lian Y, Li X, Li X, Zhang W, Deng H, Zhou M, Peng S, Li G, Xiong W. AFAP1-AS1, a long noncoding RNA upregulated in lung cancer and promotes invasion and metastasis. Tumour Biol. 2016; 37:729-37. https://doi.org/10.1007/s13277-015-3860-x.

18. Xu K, Xiong W, Zhou M, Wang H, Yang J, Li X, Chen P, Liao Q, Deng H, Li X, Li G, Zeng Z. Integrating ChIPsequencing and digital gene expression profiling to identify BRD7 downstream genes and construct their regulating network. Mol Cell Biochem. 2016; 411:57-71. https://doi. org/10.1007/s11010-015-2568-y.

19. Xiao K, Yu Z, Li X, Li X, Tang K, Tu C, Qi P, Liao Q, Chen P, Zeng Z, Li G, Xiong W. Genome-wide Analysis of Epstein-Barr Virus (EBV) Integration and Strain in C6661 and Raji Cells. J Cancer. 2016; 7:214-24. https://doi. org/10.7150/jca.13150.

20. Tu C, Zeng Z, Qi P, Li X, Yu Z, Guo C, Xiong F, Xiang B, Zhou M, Gong Z, Liao Q, Yu J, He Y, et al. Genome-Wide Analysis of 18 Epstein-Barr Viruses Isolated from Primary Nasopharyngeal Carcinoma Biopsy Specimens. J Virol. 2017; 91:e00301-17. https://doi.org/10.1128/JVI.00301-17.

21. de Oliveira JC, Scrideli CA, Brassesco MS, Morales AG, Pezuk JA, Queiroz RP, Yunes JA, Brandalise SR, Tone LG. Differential miRNA expression in childhood acute lymphoblastic leukemia and association with clinical and biological features. Leuk Res. 2012; 36:293-8. https://doi. org/10.1016/j.leukres.2011.10.005.

22. Shi W, Alajez NM, Bastianutto C, Hui AB, Mocanu JD, Ito E, Busson P, Lo KW, Ng R, Waldron J, O’Sullivan B, Liu FF. Significance of Plk1 regulation by miR-100 in human nasopharyngeal cancer. Int J Cancer. 2010; 126:2036-48. https://doi.org/10.1002/ijc.24880.

23. Subra C, Grand D, Laulagnier K, Stella A, Lambeau G, Paillasse M, De Medina P, Monsarrat B, Perret B, SilventePoirot S, Poirot M, Record M. Exosomes account for vesicle-mediated transcellular transport of activatable phospholipases and prostaglandins. J Lipid Res. 2010; 51:2105-20. https://doi.org/10.1194/jlr.M003657.

24. Bang C, Thum T. Exosomes: new players in cell-cell communication. Int J Biochem Cell Biol. 2012; 44:2060-4. https://doi.org/10.1016/j.biocel.2012.08.007.

25. Tang MK, Wong AS. Exosomes: Emerging biomarkers and targets for ovarian cancer. Cancer Lett. 2015; 367:26-33. https://doi.org/10.1016/j.canlet.2015.07.014.

26. Batista BS, Eng WS, Pilobello KT, Hendricks-Munoz KD, Mahal LK. Identification of a conserved glycan signature for microvesicles. J Proteome Res. 2011; 10:4624-33. https://doi.org/10.1021/pr200434y.

27. Isola AL, Chen S. Exosomes: The Link between GPCR Activation and Metastatic Potential? Front Genet. 2016; 7:56. https://doi.org/10.3389/fgene.2016.00056.
28. Teng Y, Ren Y, Hu X, Mu J, Samykutty A, Zhuang X, Deng Z, Kumar A, Zhang L, Merchant ML, Yan J, Miller DM, Zhang HG. MVP-mediated exosomal sorting of miR-193a promotes colon cancer progression. Nat Commun. 2017; 8:14448. https://doi.org/10.1038/ncomms 14448.

29. Subra C, Laulagnier K, Perret B, Record M. Exosome lipidomics unravels lipid sorting at the level of multivesicular bodies. Biochimie. 2007; 89:205-12. https:// doi.org/10.1016/j.biochi.2006.10.014.

30. Tkach M, Thery C. Communication by Extracellular Vesicles: Where We Are and Where We Need to Go. Cell. 2016; 164:1226-32. https://doi.org/10.1016/j. cell.2016.01.043.

31. Raposo G, Stoorvogel W. Extracellular vesicles: exosomes, microvesicles, and friends. J Cell Biol. 2013; 200:373-83. https://doi.org/10.1083/jcb.201211138.

32. Li X, Wang S, Zhu R, Li H, Han Q, Zhao RC. Lung tumor exosomes induce a pro-inflammatory phenotype in mesenchymal stem cells via NFkappaB-TLR signaling pathway. J Hematol Oncol. 2016; 9:42. https://doi. org/10.1186/s13045-016-0269-y.

33. Caballero JN, Frenette G, Belleannee C, Sullivan R. CD9positive microvesicles mediate the transfer of molecules to Bovine Spermatozoa during epididymal maturation. PLoS One. 2013; 8:e65364. https://doi.org/10.1371/journal. pone. 0065364 .

34. Zoller M. Tetraspanins: push and pull in suppressing and promoting metastasis. Nat Rev Cancer. 2009; 9:40-55. https://doi.org/10.1038/nrc2543.

35. Zhang H, Deng T, Liu R, Bai M, Zhou L, Wang X, Li S, Wang X, Yang H, Li J, Ning T, Huang D, Li H, et al. Exosome-delivered EGFR regulates liver microenvironment to promote gastric cancer liver metastasis. Nat Commun. 2017; 8:15016. https://doi.org/10.1038/ncomms15016.

36. Yu DD, Wu Y, Shen HY, Lv MM, Chen WX, Zhang XH, Zhong SL, Tang JH, Zhao JH. Exosomes in development, metastasis and drug resistance of breast cancer. Cancer Sci. 2015; 106:959-64. https://doi.org/10.1111/cas.12715.

37. Vella LJ. The emerging role of exosomes in epithelialmesenchymal-transition in cancer. Front Oncol. 2014; 4:361. https://doi.org/10.3389/fonc.2014.00361.

38. Suchorska WM, Lach MS. The role of exosomes in tumor progression and metastasis (Review). Oncol Rep. 2016; 35:1237-44. https://doi.org/10.3892/or.2015.4507.

39. Rivoltini L, Chiodoni C, Squarcina P, Tortoreto M, Villa A, Vergani B, Burdek M, Botti L, Arioli I, Cova A, Mauri G, Vergani E, Bianchi B, et al. TNF-Related ApoptosisInducing Ligand (TRAIL)-Armed Exosomes Deliver Proapoptotic Signals to Tumor Site. Clin Cancer Res. 2016; 22:3499-512. https://doi.org/10.1158/1078-0432.CCR-152170 .

40. Luo Z, Wang Q, Lau WB, Lau B, Xu L, Zhao L, Yang H, Feng M, Xuan Y, Yang Y, Lei L, Wang C, Yi T, et al. Tumor microenvironment: The culprit for ovarian cancer 
metastasis? Cancer Lett. 2016; 377:174-82. https://doi. org/10.1016/j.canlet.2016.04.038.

41. Gong Z, Yang Q, Zeng Z, Zhang W, Li X, Zu X, Deng H, Chen P, Liao Q, Xiang B, Zhou M, Li X, Li Y, et al. An integrative transcriptomic analysis reveals p53 regulated miRNA, mRNA, and lncRNA networks in nasopharyngeal carcinoma. Tumour Biol. 2016; 37:3683-95. https://doi. org/10.1007/s13277-015-4156-x.

42. Li Q, Chen P, Zeng Z, Liang F, Song Y, Xiong F, Li X, Gong Z, Zhou M, Xiang B, Peng C, Li X, Chen X, et al. Yeast two-hybrid screening identified WDR77 as a novel interacting partner of TSC22D2. Tumour Biol. 2016; 37:12503-12. https://doi.org/10.1007/s13277-016-5113-z.

43. Liang F, Li Q, Li X, Li Z, Gong Z, Deng H, Xiang B, Zhou M, Li X, Li G, Zeng Z, Xiong W. TSC22D2 interacts with PKM2 and inhibits cell growth in colorectal cancer. Int J Oncol. 2016; 49:1046-56. https://doi.org/10.3892/ ijo.2016.3599.

44. Hornick NI, Doron B, Abdelhamed S, Huan J, Harrington CA, Shen R, Cambronne XA, Chakkaramakkil Verghese $\mathrm{S}$, Kurre P. AML suppresses hematopoiesis by releasing exosomes that contain microRNAs targeting c-MYB. Sci Signal. 2016; 9:ra88. https://doi.org/10.1126/scisignal. aaf2797.

45. Roccaro AM, Sacco A, Maiso P, Azab AK, Tai YT, Reagan M, Azab F, Flores LM, Campigotto F, Weller E, Anderson KC, Scadden DT, Ghobrial IM. BM mesenchymal stromal cell-derived exosomes facilitate multiple myeloma progression. J Clin Invest. 2013; 123:1542-55. https://doi. org/10.1172/JCI66517.

46. Zeng Z, Huang H, Huang L, Sun M, Yan Q, Song Y, Wei F, Bo H, Gong Z, Zeng Y, Li Q, Zhang W, Li X, et al. Regulation network and expression profiles of EpsteinBarr virus-encoded microRNAs and their potential target host genes in nasopharyngeal carcinomas. Sci China Life Sci. 2014; 57:315-26. https://doi.org/10.1007/s11427-0134577-y.

47. Liao Q, Zeng Z, Guo X, Li X, Wei F, Zhang W, Li X, Chen P, Liang F, Xiang B, Ma J, Wu M, Tang H, et al. LPLUNC1 suppresses IL-6-induced nasopharyngeal carcinoma cell proliferation via inhibiting the Stat3 activation. Oncogene. 2014; 33:2098-109. https://doi.org/10.1038/onc.2013.161.

48. Li D, Liu J, Guo B, Liang C, Dang L, Lu C, He X, Cheung HY, Xu L, Lu C, He B, Liu B, Shaikh AB, et al. Osteoclastderived exosomal miR-214-3p inhibits osteoblastic bone formation. Nat Commun. 2016; 7:10872. https://doi. org/10.1038/ncomms10872.

49. Xiao D, Barry S, Kmetz D, Egger M, Pan J, Rai SN, Qu J, McMasters KM, Hao H. Melanoma cell-derived exosomes promote epithelial-mesenchymal transition in primary melanocytes through paracrine/autocrine signaling in the tumor microenvironment. Cancer Lett. 2016; 376:318-27. https://doi.org/10.1016/j.canlet.2016.03.050.

50. Chao YL, Shepard CR, Wells A. Breast carcinoma cells re-express E-cadherin during mesenchymal to epithelial reverting transition. Mol Cancer. 2010; 9:179. https://doi. org/10.1186/1476-4598-9-179.

51. Banyard J, Bielenberg DR. The role of EMT and MET in cancer dissemination. Connect Tissue Res. 2015; 56:40313. https://doi.org/10.3109/03008207.2015.1060970.

52. Syn N, Wang L, Sethi G, Thiery JP, Goh BC. ExosomeMediated Metastasis: From Epithelial-Mesenchymal Transition to Escape from Immunosurveillance. Trends Pharmacol Sci. 2016; 37:606-17. https://doi.org/10.1016/j. tips.2016.04.006.

53. Qin W, Tsukasaki Y, Dasgupta S, Mukhopadhyay N, Ikebe M, Sauter ER. Exosomes in Human Breast Milk Promote EMT. Clin Cancer Res. 2016; 22:4517-24. https:/doi. org/10.1158/1078-0432.CCR-16-0135.

54. Kim J, Kim TY, Lee MS, Mun JY, Ihm C, Kim SA. Exosome cargo reflects TGF-beta1-mediated epithelialto-mesenchymal transition (EMT) status in A549 human lung adenocarcinoma cells. Biochem Biophys Res Commun. 2016; 478:643-8. https://doi.org/10.1016/j. bbrc.2016.07.124.

55. Gao D, Joshi N, Choi H, Ryu S, Hahn M, Catena R, Sadik H, Argani P, Wagner P, Vahdat LT, Port JL, Stiles B, Sukumar $\mathrm{S}$, et al. Myeloid progenitor cells in the premetastatic lung promote metastases by inducing mesenchymal to epithelial transition. Cancer Res. 2012; 72:1384-94. https://doi. org/10.1158/0008-5472.CAN-11-2905.

56. Wen D, Peng Y, Liu D, Weizmann Y, Mahato RI. Mesenchymal stem cell and derived exosome as small RNA carrier and Immunomodulator to improve islet transplantation. J Control Release. 2016; 238:166-75. https://doi.org/10.1016/j.jconrel.2016.07.044.

57. Wang S, Li X, Zhu R, Han Q, Zhao RC. Lung cancer exosomes initiate global long non-coding RNA changes in mesenchymal stem cells. Int J Oncol. 2016; 48:681-9. https://doi.org/10.3892/ijo.2015.3272.

58. Wang F, Li T, Zhang B, Li H, Wu Q, Yang L, Nie Y, Wu K, Shi Y, Fan D. MicroRNA-19a/b regulates multidrug resistance in human gastric cancer cells by targeting PTEN. Biochem Biophys Res Commun. 2013; 434:688-94. https:// doi.org/10.1016/j.bbrc.2013.04.010.

59. Tanaka Y, Kamohara H, Kinoshita K, Kurashige J, Ishimoto T, Iwatsuki M, Watanabe M, Baba H. Clinical impact of serum exosomal microRNA-21 as a clinical biomarker in human esophageal squamous cell carcinoma. Cancer. 2013; 119:1159-67. https://doi.org/10.1002/cncr.27895.

60. Qu L, Ding J, Chen C, Wu ZJ, Liu B, Gao Y, Chen W, Liu F, Sun W, Li XF, Wang X, Wang Y, Xu ZY, et al. ExosomeTransmitted lncARSR Promotes Sunitinib Resistance in Renal Cancer by Acting as a Competing Endogenous RNA. Cancer Cell. 2016; 29:653-68. https://doi.org/10.1016/j. ccell.2016.03.004.

61. Elshelmani H, Rani S. Exosomal MicroRNA Discovery in Age-Related Macular Degeneration. Methods Mol Biol. 2017; 1509:93-113. https://doi.org/10.1007/978-1-49396524-3_10. 
62. Berrondo C, Flax J, Kucherov V, Siebert A, Osinski T, Rosenberg A, Fucile C, Richheimer S, Beckham CJ. Expression of the Long Non-Coding RNA HOTAIR Correlates with Disease Progression in Bladder Cancer and Is Contained in Bladder Cancer Patient Urinary Exosomes. PLoS One. 2016; 11:e0147236. https://doi.org/10.1371/ journal.pone.0147236.

63. Au Yeung CL, Co NN, Tsuruga T, Yeung TL, Kwan SY, Leung CS, Li Y, Lu ES, Kwan K, Wong KK, Schmandt R, Lu KH, Mok SC. Exosomal transfer of stroma-derived miR21 confers paclitaxel resistance in ovarian cancer cells through targeting APAF1. Nat Commun. 2016; 7:11150. https://doi.org/10.1038/ncomms11150.

64. Alexander M, Hu R, Runtsch MC, Kagele DA, Mosbruger TL, Tolmachova T, Seabra MC, Round JL, Ward DM, O'Connell RM. Exosome-delivered microRNAs modulate the inflammatory response to endotoxin. Nat Commun. 2015; 6:7321. https://doi.org/10.1038/ncomms8321.

65. Fong MY, Zhou W, Liu L, Alontaga AY, Chandra M, Ashby J, Chow A, O’Connor ST, Li S, Chin AR, Somlo G, Palomares M, Li Z, et al. Breast-cancer-secreted miR-122 reprograms glucose metabolism in premetastatic niche to promote metastasis. Nat Cell Biol. 2015; 17:183-94. https:// doi.org/10.1038/ncb3094.

66. Ye SB, Zhang H, Cai TT, Liu YN, Ni JJ, He J, Peng JY, Chen QY, Mo HY, Jun C, Zhang XS, Zeng YX, Li J. Exosomal miR-24-3p impedes T-cell function by targeting FGF11 and serves as a potential prognostic biomarker for nasopharyngeal carcinoma. J Pathol. 2016; 240:329-40. https://doi.org/10.1002/path.4781.

67. Zhou W, Fong MY, Min Y, Somlo G, Liu L, Palomares MR, Yu Y, Chow A, O'Connor ST, Chin AR, Yen Y, Wang Y, Marcusson EG, et al. Cancer-secreted miR-105 destroys vascular endothelial barriers to promote metastasis. Cancer Cell. 2014; 25:501-15. https://doi.org/10.1016/j. ccr.2014.03.007.

68. Sakha S, Muramatsu T, Ueda K, Inazawa J. Exosomal microRNA miR-1246 induces cell motility and invasion through the regulation of DENND2D in oral squamous cell carcinoma. Sci Rep. 2016; 6:38750. https://doi.org/10.1038/ srep38750.

69. Tomasetti M, Lee W, Santarelli L, Neuzil J. Exosome-derived microRNAs in cancer metabolism: possible implications in cancer diagnostics and therapy. Exp Mol Med. 2017; 49:e285. https://doi.org/10.1038/emm.2016.153.

70. Le MT, Hamar P, Guo C, Basar E, Perdigao-Henriques R, Balaj L, Lieberman J. miR-200-containing extracellular vesicles promote breast cancer cell metastasis. J Clin Invest. 2014; 124:5109-28. https://doi.org/10.1172/JCI75695.

71. O'Brien K, Lowry MC, Corcoran C, Martinez VG, Daly M, Rani S, Gallagher WM, Radomski MW, MacLeod RA, O'Driscoll L. miR-134 in extracellular vesicles reduces triple-negative breast cancer aggression and increases drug sensitivity. Oncotarget. 2015; 6:32774-89. https://doi. org/10.18632/oncotarget.5192.
72. Di Modica M, Regondi V, Sandri M, Iorio MV, Zanetti A, Tagliabue E, Casalini P, Triulzi T. Breast cancersecreted miR-939 downregulates VE-cadherin and destroys the barrier function of endothelial monolayers. Cancer Lett. 2017; 384:94-100. https://doi.org/10.1016/j. canlet.2016.09.013.

73. Mikamori M, Yamada D, Eguchi H, Hasegawa S, Kishimoto T, Tomimaru Y, Asaoka T, Noda T, Wada H, Kawamoto K, Gotoh K, Takeda Y, Tanemura M, et al. MicroRNA-155 Controls Exosome Synthesis and Promotes Gemcitabine Resistance in Pancreatic Ductal Adenocarcinoma. Sci Rep. 2017; 7:42339. https://doi.org/10.1038/srep42339.

74. Park SM, Gaur AB, Lengyel E, Peter ME. The miR-200 family determines the epithelial phenotype of cancer cells by targeting the E-cadherin repressors ZEB1 and ZEB2. Genes Dev. 2008; 22:894-907. https://doi.org/10.1101/ gad.1640608.

75. Hu Y, Li D, Wu A, Qiu X, Di W, Huang L, Qiu L. TWEAKstimulated macrophages inhibit metastasis of epithelial ovarian cancer via exosomal shuttling of microRNA. Cancer Lett. 2017; 393:60-7. https://doi.org/10.1016/j. canlet.2017.02.009.

76. Hsu YL, Hung JY, Chang WA, Lin YS, Pan YC, Tsai PH, Wu CY, Kuo PL. Hypoxic lung cancer-secreted exosomal miR-23a increased angiogenesis and vascular permeability by targeting prolyl hydroxylase and tight junction protein ZO-1. Oncogene. 2017; 36:4929-42. https://doi.org/10.1038/onc.2017.105.

77. Ren Y, Ji N, Kang X, Wang R, Ma W, Hu Z, Liu X, Wang Y. Aberrant ceRNA-mediated regulation of KNG1 contributes to glioblastoma-induced angiogenesis. Oncotarget. 2016 Oct 14. https://doi.org/10.18632/oncotarget.12659. [Epub ahead of print].

78. Feng Q, Zhang C, Lum D, Druso JE, Blank B, Wilson KF, Welm A, Antonyak MA, Cerione RA. A class of extracellular vesicles from breast cancer cells activates VEGF receptors and tumour angiogenesis. Nat Commun. 2017; 8:14450. https://doi.org/10.1038/ncomms14450.

79. Dickman CT, Lawson J, Jabalee J, MacLellan SA, LePard NE, Bennewith KL, Garnis C. Selective extracellular vesicle exclusion of miR-142-3p by oral cancer cells promotes both internal and extracellular malignant phenotypes. Oncotarget. 2017; 8:15252-66. https://doi.org/10.18632/ oncotarget.14862.

80. Zhang Z, Li X, Sun W, Yue S, Yang J, Li J, Ma B, Wang J, Yang X, Pu M, Ruan B, Zhao G, Huang Q, et al. Loss of exosomal miR-320a from cancer-associated fibroblasts contributes to HCC proliferation and metastasis. Cancer Lett. 2017; 397:33-42. https://doi.org/10.1016/j.canlet.2017.03.004.

81. Ahadi A, Brennan S, Kennedy PJ, Hutvagner G, Tran N. Long non-coding RNAs harboring miRNA seed regions are enriched in prostate cancer exosomes. Sci Rep. 2016; 6:24922. https://doi.org/10.1038/srep24922.

82. Zhang W, Huang C, Gong Z, Zhao Y, Tang K, Li X, Fan S, Shi L, Li X, Zhang P, Zhou Y, Huang D, Liang F, et al. Expression of LINC00312, a long intergenic non-coding 
RNA, is negatively correlated with tumor size but positively correlated with lymph node metastasis in nasopharyngeal carcinoma. J Mol Histol. 2013; 44:545-54. https://doi. org/10.1007/s10735-013-9503-x.

83. Gong Z, Zhang S, Zhang W, Huang H, Li Q, Deng H, Ma J, Zhou M, Xiang J, Wu M, Li X, Xiong W, Li X, et al. Long non-coding RNAs in cancer. Sci China Life Sci. 2012; 55:1120-4. https://doi.org/10.1007/s11427-012-4413-9.

84. Fan C, Tang Y, Wang J, Xiong F, Guo C, Wang Y, Zhang S, Gong Z, Wei F, Yang L, He Y, Zhou M, Li X, et al. Role of long non-coding RNAs in glucose metabolism in cancer. Mol Cancer. 2017; 16:130. https://doi.org/10.1186/s12943017-0699-3.

85. Yu J, Liu Y, Gong Z, Zhang S, Guo C, Li X, Tang Y, Yang L, He Y, Wei F, Wang Y, Liao Q, Zhang W, et al. Overexpression long non-coding RNA LINC00673 is associated with poor prognosis and promotes invasion and metastasis in tongue squamous cell carcinoma. Oncotarget. 2017; 8:16621-32. https://doi.org/10.18632/oncotarget.14200.

86. Wang Y, Mo Y, Yang X, Zhou R, Wu Z, He Y, Yang X, Zhong Y, Du Y, Zhou H, Li X, Li Y, Li G, et al. Long non-coding RNA AFAP1-AS1 is a novel biomarker in various cancers: a systematic review and meta-analysis based on the literature and GEO datasets. Oncotarget. 2017; 8:102346-60. https://doi.org/10.18632/oncotarget.21830.

87. Wei F, Wu Y, Tang L, He Y, Shi L, Xiong F, Gong Z, Guo C, Li X, Liao Q, Zhang W, Zhou M, Xiang B, et al. BPIFB1 (LPLUNC1) inhibits migration and invasion of nasopharyngeal carcinoma through interaction with VTN and VIM. Br J Cancer. 2017 Nov 9. http://dx.doi. org/10.1038/bjc.2017.385. [Epub ahead of print].

88. Wei F, Wu Y, Tang L, Xiong F, Guo C, Li X, Zhou M, Xiang B, Li X, Li G, Xiong W, Zeng Z. Trend analysis of cancer incidence and mortality in China. Sci China Life Sci. 2017; 60:1271-75. https://doi.org/10.1007/s11427-017-9172-6.

89. Gong Z, Zhang S, Zeng Z, Wu H, Yang Q, Xiong F, Shi L, Yang J, Zhang W, Zhou Y, Zeng Y, Li X, Xiang B, et al. LOC401317, a p53-regulated long non-coding RNA, inhibits cell proliferation and induces apoptosis in the nasopharyngeal carcinoma cell line HNE2. PLoS One. 2014; 9:e110674. https://doi.org/10.1371/journal.pone.0110674.

90. Wang Y, Xue D, Li Y, Pan X, Zhang X, Kuang B, Zhou M, Li X, Xiong W, Li G, Zeng Z, Yang T. The Long Noncoding RNA MALAT-1 is A Novel Biomarker in Various Cancers: A Meta-analysis Based on the GEO Database and Literature. J Cancer. 2016; 7:991-1001. https://doi. org/10.7150/jca.14663.

91. Yu J, Liu Y, Guo C, Zhang S, Gong Z, Tang Y, Yang L, He Y, Lian Y, Li X, Deng H, Liao Q, Li X, et al. Upregulated long non-coding RNA LINC00152 expression is associated with progression and poor prognosis of tongue squamous cell carcinoma. J Cancer. 2017; 8:523-30. https://doi. org/10.7150/jca.17510.

92. Tang Y, Wang J, Lian Y, Fan C, Zhang P, Wu Y, Li X, Xiong F, Li X, Li G, Xiong W, Zeng Z. Linking long non-coding
RNAs and SWI/SNF complexes to chromatin remodeling in cancer. Mol Cancer. 2017; 16:42. https://doi.org/10.1186/ s12943-017-0612-0.

93. He B, Li W, Wu Y, Wei F, Gong Z, Bo H, Wang Y, Li X, Xiang B, Guo C, Liao Q, Chen P, Zu X, et al. EpsteinBarr virus-encoded miR-BART6-3p inhibits cancer cell metastasis and invasion by targeting long non-coding RNA LOC553103. Cell Death Dis. 2016; 7:e2353. https://doi. org/10.1038/cddis.2016.253.

94. Conigliaro A, Costa V, Lo Dico A, Saieva L, Buccheri S, Dieli F, Manno M, Raccosta S, Mancone C, Tripodi M, De Leo G, Alessandro R. CD90+ liver cancer cells modulate endothelial cell phenotype through the release of exosomes containing H19 lncRNA. Mol Cancer. 2015; 14:155. https:// doi.org/10.1186/s12943-015-0426-x.

95. Kogure T, Yan IK, Lin WL, Patel T. Extracellular VesicleMediated Transfer of a Novel Long Noncoding RNA TUC339: A Mechanism of Intercellular Signaling in Human Hepatocellular Cancer. Genes Cancer. 2013; 4:261-72. https://doi.org/10.1177/1947601913499020.

96. Pan L, Liang W, Fu M, Huang ZH, Li X, Zhang W, Zhang P, Qian H, Jiang PC, Xu WR, Zhang X. Exosomes-mediated transfer of long noncoding RNA ZFAS1 promotes gastric cancer progression. J Cancer Res Clin Oncol. 2017; 143:991-1004. https://doi.org/10.1007/s00432-017-2361-2.

97. Li T, Xie J, Shen C, Cheng D, Shi Y, Wu Z, Deng X, Chen H, Shen B, Peng C, Li H, Zhan Q, Zhu Z. Amplification of Long Noncoding RNA ZFAS1 Promotes Metastasis in Hepatocellular Carcinoma. Cancer Res. 2015; 75:3181-91. https://doi.org/10.1158/0008-5472.CAN-14-3721.

98. Zhou H, Wang F, Chen H, Tan Q, Qiu S, Chen S, Jing $\mathrm{W}, \mathrm{Yu} \mathrm{M}$, Liang $\mathrm{C}$, Ye S, Tu J. Increased expression of long-noncoding RNA ZFAS1 is associated with epithelial-mesenchymal transition of gastric cancer. Aging (Albany NY). 2016; 8:2023-38. https://doi.org/10.18632/ aging. 101048.

99. Li Q, Shao Y, Zhang X, Zheng T, Miao M, Qin L, Wang B, Ye G, Xiao B, Guo J. Plasma long noncoding RNA protected by exosomes as a potential stable biomarker for gastric cancer. Tumour Biol. 2015; 36:2007-12. https://doi. org/10.1007/s13277-014-2807-y.

100. Zhang J, Liu SC, Luo XH, Tao GX, Guan M, Yuan H, Hu DK. Exosomal Long Noncoding RNAs are Differentially Expressed in the Cervicovaginal Lavage Samples of Cervical Cancer Patients. J Clin Lab Anal. 2016; 30:111621. https://doi.org/10.1002/jcla.21990.

101. Mohankumar S, Patel T. Extracellular vesicle long noncoding RNA as potential biomarkers of liver cancer. Brief Funct Genomics. 2016; 15:249-56. https://doi. org/10.1093/bfgp/elv058.

102. Lasda E, Parker R. Circular RNAs Co-Precipitate with Extracellular Vesicles: A Possible Mechanism for circRNA Clearance. PLoS One. 2016; 11:e0148407. https://doi. org/10.1371/journal.pone.0148407. 
103. Li Y, Zheng Q, Bao C, Li S, Guo W, Zhao J, Chen D, Gu J, He X, Huang S. Circular RNA is enriched and stable in exosomes: a promising biomarker for cancer diagnosis. Cell Res. 2015; 25:981-4. https://doi.org/10.1038/cr.2015.82.

104. Wang Y, Mo Y, Gong Z, Yang X, Yang M, Zhang S, Xiong F, Xiang B, Zhou M, Liao Q, Zhang W, Li X, Li X, et al. Circular RNAs in human cancer. Mol Cancer. 2017; 16:25. https://doi.org/10.1186/s12943-017-0598-7.

105. He R, Liu P, Xie X, Zhou Y, Liao Q, Xiong W, Li X, Li G, Zeng Z, Tang H. circGFRA1 and GFRA1 act as ceRNAs in triple negative breast cancer by regulating miR-34a. J Exp Clin Cancer Res. 2017; 36:145. https://doi.org/10.1186/ s13046-017-0614-1.

106. Liu Q, Zhang X, Hu X, Dai L, Fu X, Zhang J, Ao Y. Circular RNA Related to the Chondrocyte ECM Regulates MMP13 Expression by Functioning as a MiR-136 'Sponge' in Human Cartilage Degradation. Sci Rep. 2016; 6:22572. https://doi.org/10.1038/srep22572.

107. Zheng Q, Bao C, Guo W, Li S, Chen J, Chen B, Luo Y, Lyu D, Li Y, Shi G, Liang L, Gu J, He X, et al. Circular RNA profiling reveals an abundant circHIPK3 that regulates cell growth by sponging multiple miRNAs. Nat Commun. 2016; 7:11215. https://doi.org/10.1038/ncomms11215.

108. Hansen TB, Jensen TI, Clausen BH, Bramsen JB, Finsen B, Damgaard CK, Kjems J. Natural RNA circles function as efficient microRNA sponges. Nature. 2013; 495:384-8. https://doi.org/10.1038/nature11993.

109. Lu D, Xu AD. Mini Review: Circular RNAs as Potential Clinical Biomarkers for Disorders in the Central Nervous System. Front Genet. 2016; 7:53. https://doi.org/10.3389/ fgene.2016.00053.

110. Dou Y, Cha DJ, Franklin JL, Higginbotham JN, Jeppesen DK, Weaver AM, Prasad N, Levy S, Coffey RJ, Patton JG, Zhang B. Circular RNAs are down-regulated in KRAS mutant colon cancer cells and can be transferred to exosomes. Sci Rep. 2016; 6:37982. https://doi.org/10.1038/ srep37982.

111. Xu L, Zhang Y, Qu X, Che X, Guo T, Cai Y, Li A, Li D, Li C, Wen T, Fan Y, Hou K, Ma Y, et al. E3 Ubiquitin Ligase Cbl-b Prevents Tumor Metastasis by Maintaining the Epithelial Phenotype in Multiple Drug-Resistant Gastric and Breast Cancer Cells. Neoplasia. 2017; 19:374-82. https://doi.org/10.1016/j.neo.2017.01.011.

112. Savina A, Furlan M, Vidal M, Colombo MI. Exosome release is regulated by a calcium-dependent mechanism in K562 cells. J Biol Chem. 2003; 278:20083-90. https://doi. org/10.1074/jbc.M301642200.

113. Buck AH, Coakley G, Simbari F, McSorley HJ, Quintana JF, Le Bihan T, Kumar S, Abreu-Goodger C, Lear M, Harcus Y, Ceroni A, Babayan SA, Blaxter M, et al. Exosomes secreted by nematode parasites transfer small RNAs to mammalian cells and modulate innate immunity. Nat Commun. 2014; 5:5488. https://doi.org/10.1038/ncomms6488.

114. Wang W, Li X, Zheng D, Zhang D, Huang S, Zhang X, Ai F, Wang X, Ma J, Xiong W, Zhou Y, Li G, Shen S. Dynamic changes of peritoneal macrophages and subpopulations during ulcerative colitis to metastasis of colorectal carcinoma in a mouse model. Inflamm Res. 2013; 62:66980. https://doi.org/10.1007/s00011-013-0619-y.

115. Mittelbrunn M, Gutierrez-Vazquez C, Villarroya-Beltri C, Gonzalez S, Sanchez-Cabo F, Gonzalez MA, Bernad A, Sanchez-Madrid F. Unidirectional transfer of microRNAloaded exosomes from T cells to antigen-presenting cells. Nat Commun. 2011; 2:282. https://doi.org/10.1038/ncomms1285.

116. Huang Z, Feng Y. Exosomes Derived From Hypoxic Colorectal Cancer Cells Promote Angiogenesis Through Wnt4-Induced beta-Catenin Signaling in Endothelial Cells. Oncol Res. 2017; 25:651-61. https://doi.org/10.3727/0965 04016X14752792816791.

117. Yin Y, Cai X, Chen X, Liang H, Zhang Y, Li J, Wang Z, Chen X, Zhang W, Yokoyama S, Wang C, Li L, Li L, et al. Tumor-secreted miR-214 induces regulatory T cells: a major link between immune evasion and tumor growth. Cell Res. 2014; 24:1164-80. https://doi.org/10.1038/cr.2014.121.

118. Qin X, Yu S, Xu X, Shen B, Feng J. Comparative analysis of microRNA expression profiles between A549, A549/ DDP and their respective exosomes. Oncotarget. 2017; 8:42125-35. https://doi.org/10.18632/oncotarget.15009.

119. Chen WX, Liu XM, Lv MM, Chen L, Zhao JH, Zhong SL, Ji MH, Hu Q, Luo Z, Wu JZ, Tang JH. Exosomes from drug-resistant breast cancer cells transmit chemoresistance by a horizontal transfer of microRNAs. PLoS One. 2014; 9:e95240. https://doi.org/10.1371/journal.pone.0095240.

120. Zheng P, Chen L, Yuan X, Luo Q, Liu Y, Xie G, Ma Y, Shen L. Exosomal transfer of tumor-associated macrophagederived miR-21 confers cisplatin resistance in gastric cancer cells. J Exp Clin Cancer Res. 2017; 36:53. https:// doi.org/10.1186/s13046-017-0528-y.

121. Hou Y, Zhu Q, Li Z, Peng Y, Yu X, Yuan B, Liu Y, Liu Y, Yin L, Peng Y, Jiang Z, Li J, Xie B, et al. The FOXM1-ABCC5 axis contributes to paclitaxel resistance in nasopharyngeal carcinoma cells. Cell Death Dis. 2017; 8:e2659. https://doi. org/10.1038/cddis.2017.53.

122. Sansone P, Berishaj M, Rajasekhar VK, Ceccarelli C, Chang Q, Strillacci A, Savini C, Shapiro L, Bowman RL, Mastroleo C, De Carolis S, Daly L, Benito-Martin A, et al. Evolution of Cancer Stem-like Cells in EndocrineResistant Metastatic Breast Cancers Is Mediated by Stromal Microvesicles. Cancer Res. 2017; 77:1927-41. https://doi. org/10.1158/0008-5472.CAN-16-2129.

123. Chen Y, Zeng C, Zhan Y, Wang H, Jiang X, Li W. Aberrant low expression of $\mathrm{p} 85 \mathrm{alpha}$ in stromal fibroblasts promotes breast cancer cell metastasis through exosome-mediated paracrine Wnt10b. Oncogene. 2017; 36:4692-705. https:// doi.org/10.1038/onc.2017.100.

124. Sun X, Ma X, Wang J, Zhao Y, Wang Y, Bihl JC, Chen Y, Jiang C. Glioma stem cells-derived exosomes promote the angiogenic ability of endothelial cells through miR-21/ VEGF signal. Oncotarget. 2017; 8:36137-48. https://doi. org/10.18632/oncotarget.16661. 
125. Bobrie A, Krumeich S, Reyal F, Recchi C, Moita LF, Seabra MC, Ostrowski M, Thery C. Rab27a supports exosomedependent and -independent mechanisms that modify the tumor microenvironment and can promote tumor progression. Cancer Res. 2012; 72:4920-30. https://doi. org/10.1158/0008-5472.CAN-12-0925.

126. An T, Qin S, Xu Y, Tang Y, Huang Y, Situ B, Inal JM, Zheng L. Exosomes serve as tumour markers for personalized diagnostics owing to their important role in cancer metastasis. J Extracell Vesicles. 2015; 4:27522. https://doi. org/10.3402/jev.v4.27522.

127. Assil S, Webster B, Dreux M. Regulation of the Host Antiviral State by Intercellular Communications. Viruses. 2015; 7:4707-33. https://doi.org/10.3390/v7082840.

128. Li L, Li C, Wang S, Wang Z, Jiang J, Wang W, Li X, Chen J, Liu K, Li C, Zhu G. Exosomes Derived from Hypoxic Oral Squamous Cell Carcinoma Cells Deliver miR-21 to Normoxic Cells to Elicit a Prometastatic Phenotype. Cancer Res. 2016; 76:1770-80. https://doi.org/10.1158/0008-5472. CAN-15-1625.

129. Sung BH, Ketova T, Hoshino D, Zijlstra A, Weaver AM. Directional cell movement through tissues is controlled by exosome secretion. Nat Commun. 2015; 6:7164. https://doi. org/10.1038/ncomms 8164 .

130. Wu L, Zhang X, Zhang B, Shi H, Yuan X, Sun Y, Pan Z, Qian H, Xu W. Exosomes derived from gastric cancer cells activate NF-kappaB pathway in macrophages to promote cancer progression. Tumour Biol. 2016; 37:12169-80. https://doi.org/10.1007/s13277-016-5071-5.

131. Hoshino A, Costa-Silva B, Shen TL, Rodrigues G, Hashimoto A, Tesic Mark M, Molina H, Kohsaka S, Di Giannatale A, Ceder S, Singh S, Williams C, Soplop N, et al. Tumour exosome integrins determine organotropic metastasis. Nature. 2015; 527:329-35. https://doi. org/10.1038/nature15756.

132. Li P, Kaslan M, Lee SH, Yao J, Gao Z. Progress in Exosome Isolation Techniques. Theranostics. 2017; 7:789-804. https://doi.org/10.7150/thno.18133.

133. Deregibus MC, Figliolini F, D’Antico S, Manzini PM, Pasquino C, De Lena M, Tetta C, Brizzi MF, Camussi G. Charge-based precipitation of extracellular vesicles. Int J Mol Med. 2016; 38:1359-66. https://doi.org/10.3892/ ijmm.2016.2759.

134. Ibsen SD, Wright J, Lewis JM, Kim S, Ko SY, Ong J, Manouchehri S, Vyas A, Akers J, Chen CC, Carter BS, Esener SC, Heller MJ. Rapid Isolation and Detection of Exosomes and Associated Biomarkers from Plasma. ACS Nano. 2017; 11:6641-51. https://doi.org/10.1021/ acsnano.7b00549.

135. Vella LJ, Scicluna BJ, Cheng L, Bawden EG, Masters CL, Ang CS, Willamson N, McLean C, Barnham KJ, Hill AF. A rigorous method to enrich for exosomes from brain tissue. J Extracell Vesicles. 2017; 6:1348885. https://doi.org/10.108 0/20013078.2017.1348885.

136. Shao H, Chung J, Lee K, Balaj L, Min C, Carter BS, Hochberg FH, Breakefield XO, Lee H, Weissleder R. Chip-based analysis of exosomal mRNA mediating drug resistance in glioblastoma. Nat Commun. 2015; 6:6999. https://doi.org/10.1038/ncomms7999. 